УДК 528:551.5:551.46:624

\title{
КЛИМАТИЧЕСКИЕ И ГИДРОЛОГИЧЕСКИЕ ФАКТОРЫ, ДЕЙСТВУЮЩИЕ В РАЙОНЕ СТВОРА ДЛЯ СТРОИТЕЛЬСТВА МОСТА «САХАЛИН-МАТЕРИК»
}

\author{
Мелкий Вячеслав Анатольевич ${ }^{1}$ \\ vamelkiy@mail.ru
}

\author{
Верхотуров Алексей Александрович1, \\ ussr-91@mail.ru
}

Пищальник Владимир Михайлович2,
vpishchalnik@rambler.ru

\section{Братков Виталий Викторович³,} vbratkov@mail.ru

\author{
1 Институт морской геологии и геофизики ДВО РАН, \\ Россия, 693022, г. Южно-Сахалинск, ул. Науки, 1 б. \\ 2 Сахалинский государственный университет, \\ Россия, 693008, г. Южно-Сахалинск, ул. Ленина, 290. \\ 3 Московский государственный университет геодезии и картографии, \\ Россия, 105064, г. Москва, Гороховский пер., 4.
}

В настоящее время ни у одного нашего современника не вызывает сомнения целесообразность перевозок по Транссибирской магистрали, а ее значение для развития Сибири и Дальнего Востока вполне очевидно. Однако такое отношение к этой транспортной артерии сформировалось не сразу. Вспомним хотя бы тот фракт, что томское купечество настояло на том, чтобы дорога проходила через Александровск (ныне Новосибирск). Решение Александра III о строительстве железной дороги сыграло судьбоносную роль. Проложенная дорога способствовала развитию городов, через которые она была проложена. Ситуация с решением вопроса об организации свободного перемещения с материка на Сахалин представляется нам схожей с той, которая была перед прокладкой линии через всю Сибирь. Вопрос придется рассматривать рано или поздно. Прокладка магистрали на остров даст мощный толчок социальному и экономическому развитию территорий, прилегающих к автомобильной и железной дороге, которые пройдут через мостовой переход. В этой статье изучается специфрика климатических и гидрологических фракторов, определяющих выбор створа гидротехнического сооружения в проливе Невельского.

Актуальность исследования продиктована потребностью во всестороннем рассмотрении условий, определяющих выбор линии пересечения Татарского пролива мостовым переходом. После рассмотрения влияния геологических и геоморфрологических фракторов следует уделить внимание климатическим, погодным и гидрологическим процессам, которые будут оказывать постоянное воздействие на сооружение в период строительства и эксплуатации.

Цель: свести воедино и проанализировать данные, характеризующие особенности атмоссрерных и гидросфрерных процессов в узкой части Татарского пролива, и провести научные исследования, которые послужат дополнением к инженерным изысканиям и помогут на основе моделирования выявить наиболее безопасньй створ для возведения гидротехнического сооружения, которое соединит берега.

Материалы и методы. Материалами для исследования послужили картографические материалы, данные дистанционного зондирования Земли, сведения о климатических и погодных условиях, данные гидрологических, метеорологических, океанографических наблюдений, информация, полученная в результате научно-исследовательских работ и инженерных изысканий, в которых принимали участие авторы, а также сведения из литературных источников. Картографрирование в геоинформационной среде позволило создать тематические карты, отражающие динамику гидрометеорологических процессов. Полученная инфрормация использовалась при построении моделей циркуляции вод, становления и деградации ледяного покрова в проливе Невельского с применением геоинформационных технологий. Авторы принимали непосредственное участие в исследованиях створа «Новый» в 2001 2.

В результате изучения особенностей гидрометеорологических условий в пределах акватории пролива Невельского и его побережий, основанных на данных спутникового мониторинга, наблюдений на близлежащих метеостанциях, а также подтвержденных информацией, полученной во время изысканий, установлено, что в районе пролива Невельского неблагоприятные явления природы следует учесть при принятии технических проектных решений по выбору типа мостового или тоннельного перехода с материка на Сахалин. Пространственно-временное распределение сияния в районе обусловлено астрономическими причинами, а снижение продолжительности солнечного сияния в Де-Кастри и Погиби по сравнению с Николаевском-на-Амуре связано с частыми туманами, возникающими при атмосферных процессах на границе суши и моря. Экстремальные значения температуры воздуха в Погиби зарегистрированы на метеостанции Погиби - максимум $27,3{ }^{\circ} \mathrm{C}$ и минимум - $-44,0^{\circ} \mathrm{C}$. Индекс континентальности весьма высокий (амплитуда $71,3^{\circ} \mathrm{C}$ ), что можно объяснить влиянием выноса воздушных масс с материка в зимний период. Важньй для проектирования показатель - продолжительность безморозного периода - колеблется в Погиби от 88 до 186 дней (среднее значение - 137). Суточные суммы осадков теплого периода достигали максимальных значений 88 мм в октябре, 81 - в августе и 78 - в июле. Снежный покров в Погиби держится от 153 до 216 дней. Ветер $\geq 30$ м/с случается весной и осенью ежегодно, иногда превышает $40 \mathrm{~m} / \mathrm{c}$. Туманы в описываемом районе наблюдаются в течение всего года. Метели в проливе и на его берегах очень частое явление. Любое усиление ветра зимой сопровождается метелевым переносом снега. Грозы случаются 4-5 раз в году. Пыльные бури бывают редко. Горизонтальная 
циркуляция воды в северной части пролива зимой имеет антициклоническую направленность, с мая по сентябрь действует циклоническая циркуляция. В иелом весной на поверхности скорости движения вод составляют 2-7 см/с, а летом уменьшаются до 1-4 см/с. Изменения уровня моря в Татарском проливе находятся в диапазоне 3,2-4 м. Продолжительность ледового периода в умеренные типы зим составляет $201 \mathrm{cym}$. Толщина припая в Погиби в конце марта-начале апреля в среднем составляет 160 см и варьирует от 119 до 190 см в зависимости от типа зимы. Из-за сильных приливных течений сплошной ледяной покров в канале средней части пролива формируется крайне редко и на непродолжительное время. Следствием повышенной динамики ледяного покрова является многократное наслоение молодых льдов толщиной до 30 см. Берега в южной части пролива обладают устойчивостью к абразионным процессам и практически не разрушаются. Результаты изучения климатических и гидрологических условий показали, что строительство мостового перехода в проливе Невельского возможно. Наиболее благоприятными условиями для строительства сооружения обладает район, заключенный между линиями створов м. Лазарева - м. Погиби на севере и м. Южный - м. Тык на юге, климатические и гидрологические условия на всем протяжении имеют относительное сходство, что позволило нам выделить его при районировании как самостоятельную единицу. Выполненные исследования позволяют отдать преимущество створу «Новый» (м. Невельского - м. Лах).

\section{Ключевые слова:}

Гидрометеорологические условия, космические снимки, тематическое картограффирование,

ледовая обстановка, абразия берегов, геодезическое обеспечение, геоинформационные технологии.

\section{Введение}

В статье, посвященной анализу геологических и геоморфологических факторов, определяющих выбор створа для строительства транспортного перехода с материка на Сахалин [1], мы обращали внимание на многовековую историю вопроса о необходимости возведения сооружения, к которому специалисты возвращались с завидным постоянством. Основные решения были приняты в 1891, 1952, 1953, 1979, 2001 гг. [2-7]. В 2017 г. президент РФ В.В. Путин заявил на Восточном экономическом форуме о том, что строительство мостового перехода «Сахалин-материк» обсуждается в структурах власти, а 24 июля 2018 г. в беседе с губернатором острова он подтвердил, что хорошо знаком с проблемой и понимает ее важность для закрепления населения в регионе. В 2019 г. полтора десятка проектных институтов ОАО «Российские железные дороги» заняты разработкой документации, необходимой для принятия стратегических и технических решений по строительству объекта. При этом довольно большое количество материалов, полученных во время изысканий, выполняемых как в настоящее время, так и ранее, не публикуется и даже не фигурирует в отчетах. В статье мы уделили особое внимание сведениям о климатических и гидрологических условиях, которые по каким-либо причинам остались «за кадром».

Анализируя сведения из различных источников, мы обнаружили, что разные авторы неоднозначно проводят границы пролива. Поэтому решили дать разъяснение по этому поводу. Проливом Невельского называют южную часть Амурского лимана от его границы, пролегающей по линии, между мысами Южный $\left(51^{\circ} 41^{\prime} \mathrm{N}, 141^{\circ} 06^{\prime} \mathrm{E}\right)$ на материковом побережье и Тык $\left(51^{\circ} 45^{\prime} \mathrm{N}, 141^{\circ} 41^{\prime} \mathrm{E}\right)$ - на сахалинском берегу, до прохода Лазарева, расположенного между мысами Лазарева $\left(52^{\circ} 14,2^{\prime} \mathrm{N}, 141^{\circ} 31,6^{\prime}\right.$ Е) и Погиби $\left(52^{\circ} 13,5^{\prime} \mathrm{N}, 141^{\circ} 38,6^{\prime} \mathrm{E}\right)$. Самое узкое место в проливе (7,5 км) находится в створе между мысами Средний и Погиби, общая протяженность составляет 56 км [8].

\section{Особенности радиационного баланса, атмосферной} циркуляции, климатические и погодные условия

Комплексное изучение гидрометеорологических условий в районе перехода выполнялось неоднократ- но с целью получения данных для принятия обоснованных проектных решений и прогнозирования вероятных изменений в результате взаимодействия с возводимым объектом.

Исследования климата и климатообразующих факторов и прогноз предстоящих изменений проводят на основе оценок линейных трендов метеорологических и океанографических характеристик, полученных за время наблюдений на станциях и со спутников [9-17]. Над акваторией дальневосточных морей выявлены разночастотные колебания климата с периодами 2-3 года (квазидвухлетние) [18], 3-7 лет (масштаба ENSO, связанные с Эль-Ниньо и Арктическим колебанием) [19, 20], 8-15 лет (квазидесятилетние или декадные, обусловленные одиннадцатилетними циклами солнечной активности) [21, 22], от 15 до 35 лет интердекадные и квазидвадцатилетние [23, 24], 50-70 лет [25]. Циклические изменения климата находят отражение в аномалиях атмосферной и океанической циркуляции, тихоокеанской муссонной системы и центров действия атмосферы. В результате этих процессов изменяются повторяемость и интенсивность циклонов, штормов местами или во всем регионе.

Климат пролива Невельского формируется под влиянием муссонного типа атмосферной циркуляции.

Солнечная радиащия. Энергетической основой большинства процессов на Земле и в ее атмосфере служит лучистая энергия Солнца. Благодаря географическому положению акватория пролива Невельского получает довольно высокое радиационное обеспечение. По данным Сахалинского и Дальневосточного территориальных управлений по гидрометеорологии $[26,27]$ годовая суммарная солнечная радиация при альбедо деятельной поверхности (29-41\%) и средних условиях облачности, измеренная на ближайших метеостанциях, составляет: в Советской Гавани - 4429, в Большом Шантаре - 4307, в

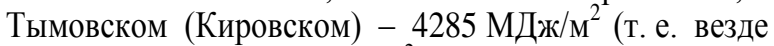
немногим более 100 ккал/см²).

Распределение суммарной солнечной радиации в пределах изучаемого района имеет хорошо выраженный сезонный ход: на станции Советская Гавань ее среднее месячное значение в зимний период составляет 
183,3 МДж/м² (4,3 ккал/см²), в весенний - 479,3 (11,4), в летний - 544,3 $(13,0)$, в осенний - 269,3 $(6,4)$.

Наименьшие значения суммарной солнечной радиации наблюдаются в декабре: от 69 МДж/м² в Б. Шантаре до 123 в Советской Гавани. В январе поток радиации увеличивается незначительно, он начинает заметно нарастать в марте и достигает максимума в конце июня - июле. Снижается количество суммарной солнечной радиации медленно и равномерно до поздней осени (рис. 1) [26, 27].
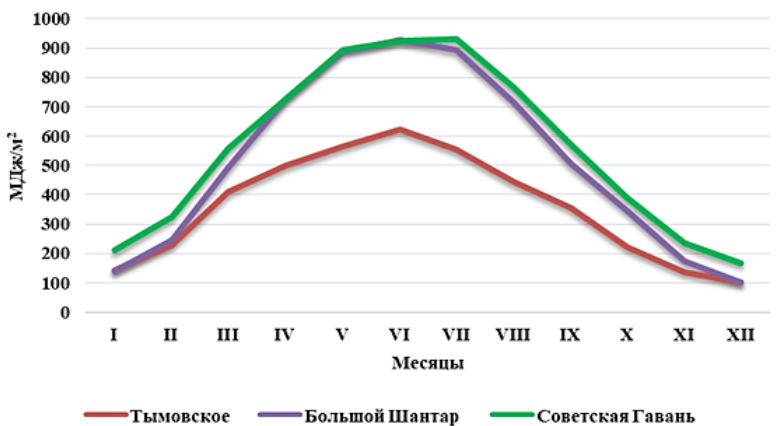

Pис. 1. Годовой ход суммарной солнечной радиации на ближайших к проливу Невельского метеостанциях

Fig. 1. Annual cycle of total solar radiation on the nearest weather stations to the Nevelskogo strait

Фактические ресурсы лучистой энергии земной поверхности характеризуются не столько суммарной солнечной радиацией, сколько радиационным балансом, который определяет тепловой режим и климатообразующие процессы территории. Годовые значения радиационного баланса в изучаемом районе находится в пределах 1182 МДж/м² в Б. Шантаре - 1600 в Советской Гавани. Радиационный баланс территории также имеет четко выраженный годовой ход (рис. 2) $[26,27]$.

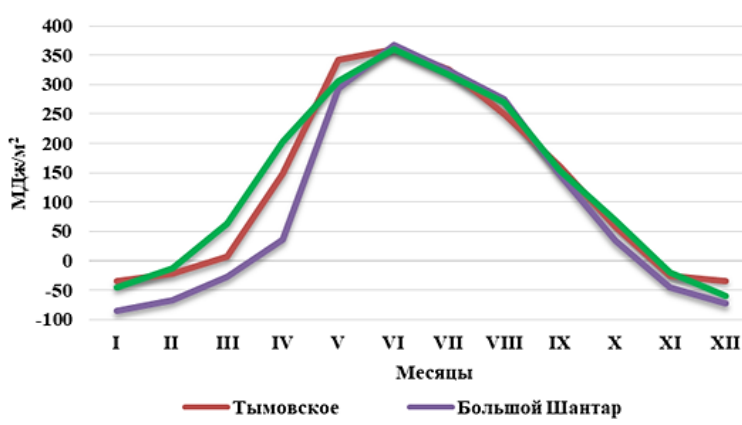

Puc. 2. Годовой ход радиаиионного баланса на ближайших к проливу Невельского метеостанциях

Fig. 2. Annual cycle of radiation balance on weather stations nearest to the Nevelskogo strait

Один из важнейших показателей световых ресурсов территории - продолжительность солнечного сияния - обычно возрастает с уменьшением широты местности и в холодный период года. В районе пролива Невельского неблагоприятные явления природы вносят коррективы в пространственно-временное распределение сияния, обусловленного астрономиче- скими причинами. Снижение продолжительности солнечного сияния в Де-Кастри и Погиби по сравнению с Николаевском-на-Амуре связано главным образом с частыми туманами, возникающими при атмосферных процессах на границе суши и моря (рис. 3) $[26,27]$.

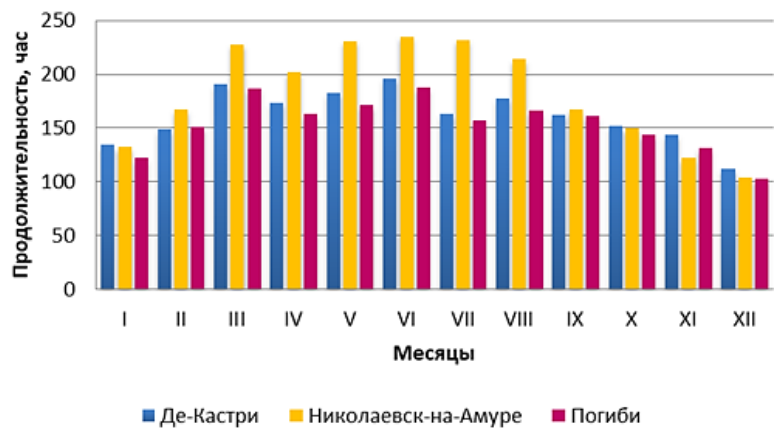

Puc. 3. Продолжительность солнечного сияния на ближайших к проливу Невельского метеостаничих

Fig. 3. Sunshine duration on weather stations nearest to the Nevelskogo strait

Температурный режим. Одной из основных климатических характеристик в любом регионе является термический режим, численной характеристикой которого является среднее многолетнее значение температуры воздуха: годовой - для общего обзора, а также месячные - для детальных. Для исследуемого района характерно наличие умеренных термических ресурсов. Наиболее высокие значения средней годовой температуры (за период наблюдений с 1936 по 2018 гг.) отмечаются на крайнем юго-востоке акватории и составляют в Александровке-Сахалинском $+0,7{ }^{\circ} \mathrm{C}$, в то время как в Погиби она $-1,6^{\circ} \mathrm{C}$, в Москальво $-1,9{ }^{\circ} \mathrm{C}$, на материке, в Николаевске-на-Амуре $-1,9{ }^{\circ} \mathrm{C}$. Средние месячные температуры на территории имеют годовой ход с одним максимумом (рис. 4). Самым холодным месяцем года является январь, самым жарким - август. Средняя температура января на станции Погиби $-19,9^{\circ} \mathrm{C}$ (от $-11,7^{\circ} \mathrm{C}$ в 1991 г. до $25,1^{\circ} \mathrm{C}$ в 1941 г.). Средняя температура августа равна $15,6{ }^{\circ} \mathrm{C}$ (от $13,7{ }^{\circ} \mathrm{C}$ в 1971 г. до 18,1 ${ }^{\circ} \mathrm{C}$ в 2006 г.). Термический режим района в целом весьма стабилен: значительных отклонений от средних многолетних характеристик не наблюдалось. Положительный тренд приземной средней месячной температуры, соответствующий ее увеличению на $0,02-0,05{ }^{\circ} \mathrm{C}$ в год, особенно значим в период с января по июнь и отмечался ранее другими исследователями [28].

Как с научной точки зрения, так и с практической стороны представляет интерес выявление экстремальных значений температуры воздуха. Абсолютный максимум температуры воздуха в Погиби, зарегистрированный 16 августа 1939 г., равен $27,3{ }^{\circ} \mathrm{C}$. Абсолютный минимум температуры воздуха равен $44,0{ }^{\circ} \mathrm{C}$ и зафиксирован 3 января 1936 г. [29]. Таким образом, $71,3{ }^{\circ} \mathrm{C}$ - это максимальная амплитуда значений температуры воздуха, отмеченная на метеостанции Погиби, которая соответствует весьма высокому индексу континентальности, что объясняется 
влиянием выноса воздушных масс с материка в зимний период. На материковом берегу в Джаоре зарегистрированы абсолютные максимум $+31,5{ }^{\circ} \mathrm{C}$ (26.06.2011 г.) и минимум $-40,9{ }^{\circ} \mathrm{C}(27.01 .2005$ г.). Вполне естественно, что амплитуда температур здесь немного больше, чем на острове.

Средняя суточная зимняя температура в Погиби $18,0^{\circ} \mathrm{C}$, января $-19,6^{\circ} \mathrm{C}$. Зачастую температура воздуха опускается ниже этого уровня. Холодные зимы наблюдались в 1941-1942, 1952-1953, 1966-1967 гг. Так, в декабре-феврале 1940 г. температура опускалась ниже $-25{ }^{\circ} \mathrm{C}$ в течение 51 дня, ниже $-30{ }^{\circ} \mathrm{C}$ в течение 27 дней. Низкие температуры (ниже $-40^{\circ} \mathrm{C}$ ) зарегистрированы в январе 1936, 1939, 1941, 1986, 1996 и 2005 гг., в декабре - 1952 г., феврале 1944 и 1950 гг.

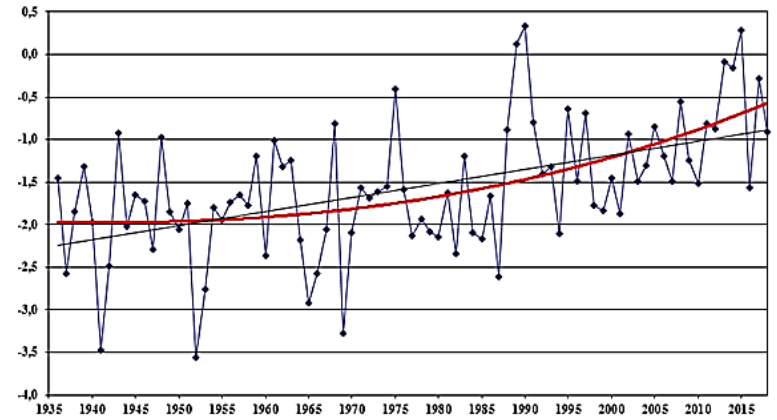

Pис. 4. Значения среднегодовых температур и тренд их изменения на метеостанции Погиби в 1936-2018 г2. (черная линия - линейньій тренд, красная - полиномиальный)

Fig. 4. Amount of annual average temperatures and trend of their changes at the weather station Pogibi for 1936-2018 (black line - linear trend, red line polynomial)

Среди основных гидрометеорологических характеристик, которые используются при проектировании

сооружений, важное место занимают даты перехода температуры через определенные значения. Расчет дат перехода средних суточных температур через заданные значения произведен по данным наблюдений на станции Погиби в период с 1936 по 2018 гг. (рис. 5) (табл. 1, 2) [29].

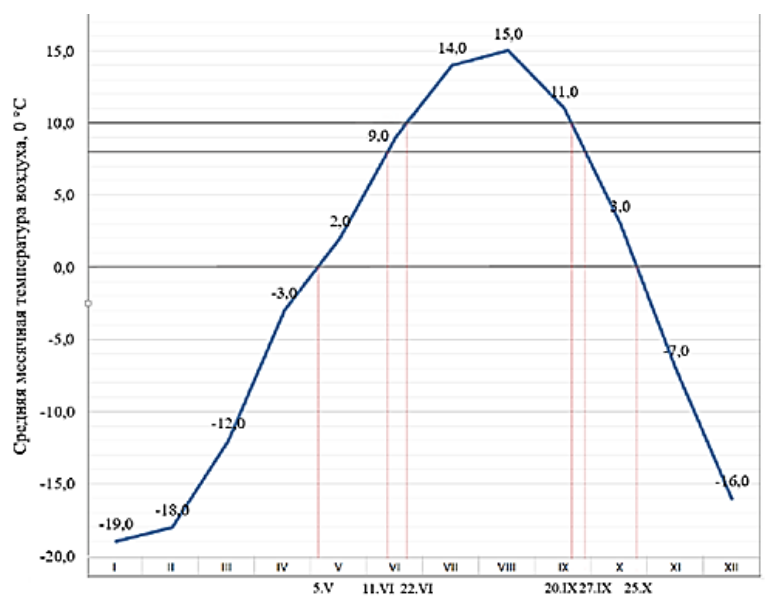

Pис. 5. График годового хода средних месячных температур и определение дат перехода их средних суточных величин через заданные значения 0, 8, $10{ }^{\circ} \mathrm{C}$ в Погиби

Fig. 5. Schedule of the annual course of average monthly temperatures and determination of the dates of transition of average daily temperatures through the set values of $0,8,10^{\circ} \mathrm{C}$ in Pogibi

Таблица 1. Средние даты устойчивого перехода средней суточной температуры через заданные значения

Table 1. Average dates of steady transition of average daily temperature through set values

\begin{tabular}{|l|c|c|c|c|c|c|}
\hline $\begin{array}{l}\text { Пункты наблюдения } \\
\text { Observing station }\end{array}$ & $0{ }^{\circ} \mathrm{C} \uparrow$ & $8{ }^{\circ} \mathrm{C} \uparrow$ & $10{ }^{\circ} \mathrm{C} \uparrow$ & $10{ }^{\circ} \mathrm{C} \downarrow$ & $8{ }^{\circ} \mathrm{C} \downarrow$ & $0^{\circ} \mathrm{C} \downarrow$ \\
\hline $\begin{array}{l}\text { Погиби } \\
\text { Pogibi }\end{array}$ & 05.05 & 11.06 & 21.06 & 20.09 & 27.09 & 25.10 \\
\hline
\end{tabular}

Таблица 2. Даты (год) первого и последнего заморозка и продолжительность безморозного периода (по среднесуточным измерениям) в воздухе

Table 2. Dates (year) of first and last freeze and duration of frost-free period (according average daily measurements) in air

\begin{tabular}{|c|c|c|c|c|c|c|c|c|c|}
\hline \multirow{2}{*}{$\begin{array}{c}\text { Пункты } \\
\text { наблюдения } \\
\text { Observing } \\
\text { station }\end{array}$} & \multicolumn{3}{|c|}{$\begin{array}{c}\text { Дата последнего заморозка } \\
\text { Date last freeze }\end{array}$} & \multicolumn{3}{|c|}{$\begin{array}{l}\text { Дата первого заморозка } \\
\text { Date first freeze }\end{array}$} & \multicolumn{3}{|c|}{$\begin{array}{c}\text { Продолжительность безморозного периода, дни } \\
\text { Frost-free period, days }\end{array}$} \\
\hline & $\begin{array}{l}\text { средняя } \\
\text { average }\end{array}$ & $\begin{array}{c}\text { ранняя } \\
\text { early }\end{array}$ & $\begin{array}{l}\text { поздняя } \\
\text { late }\end{array}$ & $\begin{array}{l}\text { средняя } \\
\text { average }\end{array}$ & $\begin{array}{c}\text { ранняя } \\
\text { early }\end{array}$ & $\begin{array}{l}\text { поздняя } \\
\text { late }\end{array}$ & $\begin{array}{l}\text { средняя } \\
\text { average }\end{array}$ & $\begin{array}{l}\text { наимен. } \\
\text { min }\end{array}$ & $\begin{array}{l}\text { наибол. } \\
\max \end{array}$ \\
\hline $\begin{array}{c}\text { Погиби } \\
\text { Pogibi }\end{array}$ & 03.06 & $\begin{array}{l}10.05 \\
2000 \\
2001\end{array}$ & $\begin{array}{c}28.06 \\
1937\end{array}$ & 25.10 & $\begin{array}{c}15.09 \\
1998\end{array}$ & $\begin{array}{l}04.11 \\
2011 \\
2018\end{array}$ & 137 & $\begin{array}{c}88 \\
1938\end{array}$ & $\begin{array}{c}186 \\
2018\end{array}$ \\
\hline
\end{tabular}

Атмосферное давление в Погиби варьирует от 916,6 (687 мм ртутного столба) в 1976 г. до 1041,7 гПа (781,3 мм рт. ст.) в 1971 г. (среднегодовое от 1009,0 до 1012). На материке в Джаоре оно изменялось от 904,2 (1972) до 1055,9 гПа (2017).

Годовой ход парциального давления водяного пара в Погиби имеет выраженный характер, среднее годовое значение составляет 6,4 гПа, наиболее низким является среднеянварское - 1,1 , наиболее высоким среднее за август - 15,5 гПа. Средняя месячная относительная влажность воздуха $\left(f_{\text {cp. }}\right)$ наиболее хо- лодного месяца составляет 82 \%, наиболее теплого 88 \%. В Джаоре влажность воздуха несколько ниже: в январе $-75 \%$, в августе $-80 \%$.

Осадки. Самыми «мокрыми» в Погиби были годы 1994, 1995 и 2000, когда годовое количество выпавших осадков составило 880, 802 и 765 мм соответственно. Месячная сумма осадков достигала 209 мм в сентябре 1995 г., 192 мм в октябре 1997 г., 223 мм в июле 2019 г. Суточные максимумы в эти годы не превышали нормы, своих наибольших значений они достигали 27 июля 1992 г. (78 мм) и 24 июля 1990 г. 
(64 мм). Суточные суммы выпавших осадков достигали максимальных значений 88 мм в октябре 1944 г., 81 - в августе 1957 г. и 78 - в июле 1992 г. По числу дней с дождями рекордсменами стали 1970-е годы (более 100 дождливых дней отмечено в 1971, 1972, 1974, 1975, 1978, 1979, 1981, 1982 гг.), большим количеством дней (более 90) со снегопадами «отметились» 1971, 1974, 1976, 1977, 1987, 1999, 2010, 2013 гг. [29].

На материковом берегу (Джаоре) большое годовое количество осадков выпадало в 2010 г. (1023 мм), 2004 г. (986 мм), 1988 г. (888 мм). В «мокрые» для Погиби годы в Джаоре также выпадало значительное количество осадков (более 700 мм). Суточные максимумы здесь отмечались 18 августа 2006 г. (91 мм) и 9 августа и 1 сентября 2004 г. по 78 мм.

Один из самых разрушительных для Сахалина тайфун Филлис (№ 198112), зародившийся в районе о. Гуам, прошедший начале августа 1981 г. через север Японии, Приморский, Хабаровский край, Амурскую область (время жизни составило 144 часа), в Погиби и Джаоре отметился обычным дождем и ветром с порывами до 15-20 м/сек.

Снежный покров в Погиби держится весьма продолжительное время от 153 в 1973 г. до 216 дней 2006 г. Обычно он устойчив со второй половины сентября по первую декаду мая. Так, в 1976 г. число дней, в которые наблюдались снегопады, составило 116. Наибольшая высота снежного покрова - 250 см наблюдалась на метеостанции 18 мая 2000 г. Сход снега может затянуться до конца мая - начала июня. Иногда возможны интенсивные снегопады даже во второй половине мая, как в 2000 г. После событий такого рода наблюдается быстрое снеготаяние, приводящее к паводкам на реках. Частые метели отмечены наблюдателями метеостанции в 1969 г. (29), 1980 г. (19), 1991 г. (15), 2001 г. (14) и 2013 г. (21 раз); в 1970-е годы число метелей, наблюдаемых за зиму, превышало 20 (исключение 1975, 1977 гг.) [29].

Bempbl. Средняя скорость ветра в Погиби в холодный период со средней суточной температурой воздуха $\leq 8{ }^{\circ} \mathrm{C}$ составляет $4,5 \mathrm{M} / \mathrm{c}$.

Сильные ветры наблюдались в течение многих лет в среднем 80-110 дней, в отдельные годы их число доходило до 155 дней. Число дней со скоростью ветра свыше $15 \mathrm{~m} / \mathrm{c}$ в Погиби в среднем за год составляет 15-30\%. В зимний период сильный ветер в Погиби может дуть 15-25 дней в месяц.

Ветры со скоростью $\geq 20 \mathrm{M} / \mathrm{c}$ в Погиби случаются в любой месяц года. Скорость ветра от 25 до $30 \mathrm{~m} / \mathrm{c}$ отмечается в период с сентября по март в течение любого месяца 1-2 раза ежегодно, летом - 1 раз в два года, более $30 \mathrm{~m} / \mathrm{c}-1-3$ раза в месяц в ноябре-апреле. В августе ветер $\geq 30 \mathrm{~m} / \mathrm{c}$ бывает также ежегодно, в мае и октябре - 3 раза в 10 лет. Максимальные скорости ветра $\geq 40$ м/с отмечались по флюгеру лишь иногда: в марте 1971 г., ноябре 1974 г., апреле 2017 г. [31].

В осенне-зимний период в районе преобладают ветры северного, западного и северо-западного направлений, весной - восточного и юго-восточного, летом - юго-западного [29].
Сильные ветры отмечаются на побережье у мысов, где наблюдается их ускорение при обтекании препятствий, а также над открытой водной поверхностью. Юго-восточные ветры летом сопровождаются осадками.

Атмосферные явления. Туманы в проливе бывают в течение всего года. Наиболее часто отмечались в теплое время года, особенно в конце августа. Туманы имеют приуроченность к дождливым годам: более 35 дней за год с туманами наблюдались в те же 1970-е гг., а в 1975 и 1978 гг. туманными были более 50 дней.

Метели в проливе и на его берегах очень частое явление. Любое усиление ветра зимой сопровождается метелевым переносом снега. За зиму случается от 5 до 30 метелей. Больше 10 раз в зимний период метели наблюдались в течение 32 лет за время наблюдений с 1971 г. $(66 \%)$.

Грозы - явление для Сахалина и пролива довольно редкое. В среднем гроза случается 4-5 раз в году. Отмечены годы, когда грозы не было вовсе (1981, 1989, 1993, 2017 гг.). Иногда грозы происходят почаще: в 2007 г. - 10, в 1975 г. - 13, а в 1973 г. даже 15 раз.

Пыльные бури в районе пролива тоже наблюдались в течение 11 лет (23 \%) за период наблюдений, а изредка более одного раза: в 1989 г. - 2; 1976 г. - 5; 1973 и 1975 гг. по 7; а в 1972 г. - 8 [29].

\section{Результаты исследования гидрологического режима и океанографических особенностей пролива}

Гидродинамический режим пролива Невельского крайне сложный [30]. Пролив представляет собой своеобразный канал, соединяющий Охотское и Японское море. Течения в нем испытывают мощное влияние пятой в мире по площади водосбора реки Амур.

Движение вод детально исследовалось нами при моделировании циркуляции водных масс [31]. Перенос морских вод через пролив Невельского тесно связан с гидрологическим режимом устьевой области реки Амур. Средние месячные значения расходов воды рассчитаны в проливе балансовым методом с учетом разности солености воды между Амурским лиманом и Татарским проливом за 1963-1980 гг. по результатам моделирования на северной границе Татарского пролива [32, 33].

Анализ наблюдений в проливе Невельского позволил определить направления переносов воды в проливе: с севера на юг с октября по май и с юга на север с июня по сентябрь [32]. Модельные расчеты, выполненные нами позднее, показали, что расходы водных масс менялись в декабре-марте в пределах от 0,1 до 12,7 , а в мае-сентябре от 27,3 до $128,1 \mathrm{~km}^{3} / \mathrm{Mec}$. (табл. 3).

Расчеты, выполненные при проведении исследований, позволяют сделать вывод о том, что при значительных расходах воды в вершине устьевой части р. Амур в летнее время вся масса воды не может пройти через пролив Невельского, часть ее уходит через Амурский лиман к северу в Сахалинский залив, тем не менее общая направленность движения вод с севера на юг в проливе в летнее время сохраняется. 
Таблица 3. Средние месячные значения расходов воды (км³) (знак минус означает направление потока с севера на юг) [31]

Table 3. Average monthly values of water consumption $\left(\mathrm{km}^{3}\right)$ (minus sign means stream direction from north to south) [31]

\begin{tabular}{|l|c|c|c|c|c|c|c|}
\hline Суммарный расход воды/Total water consumption & I & II & III & IV & V & VI & VII \\
\hline По Л.П. Якунину/Ву L.P. Yakunin & $-7,0$ & $-5,3$ & $-3,7$ & $-2,5$ & $-7,9$ & 15,6 & 15,6 \\
\hline По А.В. Леонову и др./By A.V. Leonov et al. & $-0,7$ & $-0,3$ & $-0,2$ & $-0,1$ & $-46,9$ & $-70,5$ & $-97,3$ \\
\hline & VIII & IX & X & XI & XII & Год/Year & - \\
\hline По Л.П. Якунину/By L.P. Yakunin & 3,8 & 10,8 & $-0,9$ & $-13,4$ & $-10,4$ & $-5,3$ & - \\
\hline По А.В. Леонову и др./By A.V. Leonov et al. & $-128,1$ & $-27,3$ & $-13,6$ & $-14,5$ & $-12,7$ & $-412,2$ & - \\
\hline
\end{tabular}

$h, \mathbf{M}$
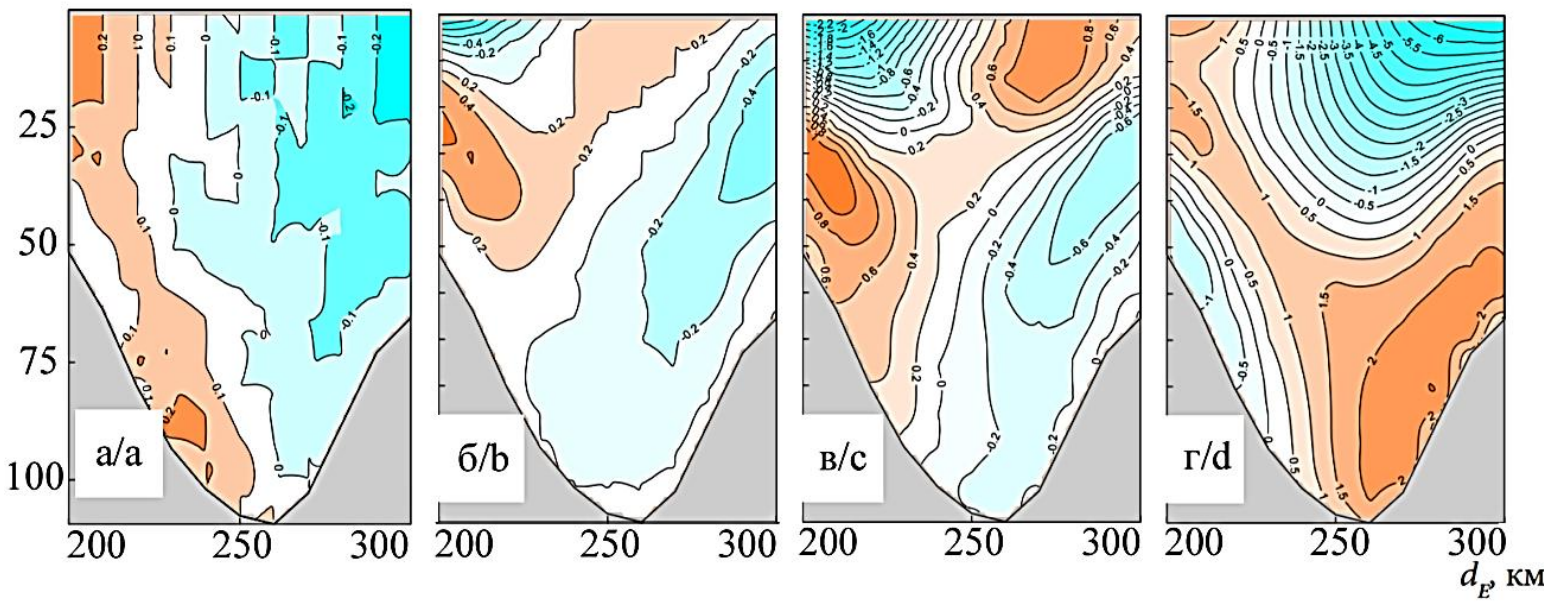

Рис. 6. Распределение меридиональной составляющей скорости течения (см/с) в северной части Татарского пролива по сезонам: а) зимой; б) весной; в) летом; г) осенью

Fig. 6. Distribution of meridional component of flow velocity $(\mathrm{cm} / \mathrm{s})$ in northern part of the Tatar Strait seasonable: a) winter; b) spring; c) summer; d) autumn

Движение вод на севере Татарского пролива зимой имеет антициклоническую направленность. Весной под воздействием муссона на поверхности возникает циклонический круговорот водных масс. Летом поток северного направления проходит вдоль берега острова, скорость течений в верхних слоях доходит до $2,2 \mathrm{~cm} / \mathrm{c}$ (рис. 6). Осенью в пролив Невельского поступают большие объемы вод р. Амур, что приводит к смене направления движения вод на циклоническое [34].

Поступление амурского стока завершается с началом ледостава. Зимой в проливе устанавливается слабая антициклоническая циркуляция вод, которая существует до разрушения льда и начала летнего муссона [31].

Обобщенные схемы горизонтальной циркуляции вод для сезонов с учетом образования вихревых структур показывают, что зимой во всей толще вод мелководной части пролива к северу от $49^{\circ} 30^{\prime}$ с. ш. поддерживается слабая антициклоническая циркуляция вод. В апреле в северной части пролива в поверхностном слое воды следуют на юг. В мае по мере развития летнего муссона начинает формироваться циклоническая циркуляция вод, обуславливающая подъем вод до начала осеннего (сентябрь) изменения направления движения воды. В целом весной на поверхности скорости движения вод составляют 2$7 \mathrm{~cm} / \mathrm{c}$, а летом уменьшаются до $1-4 \mathrm{~cm} / \mathrm{c}$. Абсолютные значения вертикальных скоростей весьма малы.
В проливе Невельского отсутствуют станции наблюдения за уровнем моря, поэтому на основе данных в ближайших пунктах наблюдения определено, что суммарные экстремальные уровни моря (табл. 4), вызываемые сгонно-нагонными явлениями, не превышают 2 м.

Таблица 4. Отклонения суммарных экстремальных уровней моря на побережье Японского моря [35]

Table 4. Deviations of total extreme sea levels on coast of the Sea of Japan

\begin{tabular}{|l|c|c|c|}
\hline $\begin{array}{c}\text { Пункты } \\
\text { орблюдения } \\
\text { station }\end{array}$ & $\begin{array}{c}\text { Максимум } \\
\text { выше } \\
\text { среднего } \\
\text { Maximum } \\
\text { above average }\end{array}$ & $\begin{array}{c}\text { Максимум } \\
\text { ниже } \\
\text { среднего } \\
\text { Maximum } \\
\text { below average }\end{array}$ & $\begin{array}{c}\text { Максимальный } \\
\text { размах } \\
\text { колебаний } \\
\text { Махіmum } \\
\text { amplitude of } \\
\text { oscillations }\end{array}$ \\
\hline $\begin{array}{l}\text { Де-Кастри } \\
\text { De-Каstri }\end{array}$ & 187 & -207 & 394 \\
\hline $\begin{array}{l}\text { Александровск- } \\
\text { Сахалинский } \\
\begin{array}{l}\text { Aleksandrovsk- } \\
\text { Sakhalinskiy }\end{array}\end{array}$ & 161 & -163 & 324 \\
\hline
\end{tabular}

Уровень моря в проливе Невельского меняется в диапазоне 3,2-4 м, что связано с вариациями плотности воды и атмосферного давления. Уменышение плотности летом вместе со обильным поступлением водных масс с юга приводит к повышению среднего уровня в проливе, зимой наблюдается его понижение, вызываемое процессами обратной направленности. Размах колебаний уровня в течение года оставляет 19-20 см (рис. 7). 


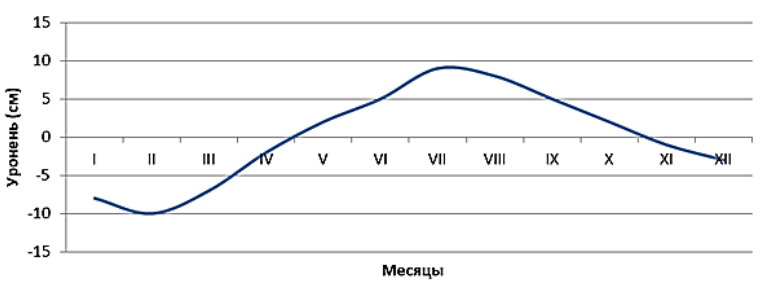

Рис. 7. Средний годовой ход уровня моря в Александровске-Сахалинском

Fig 7. Average annual cycle of sea level in AleksandrovskSakhalinskiy

В летнее время преобладает волнение южного направления. Преобладающая высота волн $0,5-0,7 \mathrm{~m}$. У берегов высота волне не превышает 1,5 м. В фарватерной части пролива влияние волнения на дно незначительное. Ближе к берегу происходит взмучивание донного грунта мощностью до 20 см. Режим волнения отличается наибольшей интенсивностью в зимнее время: длительность штормов доходит до 6-7 суток при скорости ветра 40-70 м/с. Весной часты волнения силой 2-5 баллов (около $70 \%$ ), вызываемые ветрами южных направлений [36].

Интенсивность и продолжительность штормовых нагонов обусловлены направлением подхода волн к берегу, а также рельефом дна и шириной шельфовой полки. Ключевым фактором их возникновения является направление (преобладает южное) и продолжительность действия ветра.

Волны-цунами возникают на побережье пролива вследствие землетрясений. В проливе выделен район с пороговой магнитудой 6,5. При цунамигенном землетрясении 5 сентября 1971 г. при магнитуде $\mathrm{M}=6,9$ образовалась волна высотой 2,05 м на западном побережье Сахалина. Землетрясение, произошедшее 2 августа 2007 г. $(\mathrm{M}=6,2)$, сопровождалось цунами высотой 3,2 м в районе г. Невельска [37].

Ледостав в районе г. Николаевск-на-Амуре фиксируется в начале второй декады ноября. Первое появление льда на ГМС Погиби зафиксировано 5 ноября, окончательное очищение - 25 мая. Продолжительность ледового периода в умеренные типы зим составляет 201 сут. В зависимости от суровости зимы смещение дат наступления ледовых фаз может происходить со смещением на $\pm 12-14$ сут.

Припай в Амурском лимане, в мелководных заливах вдоль сахалинского берега от м. Погиби до м. Тык и по линии, соединяющей мысы ЛазареваСредний-Муравьёва-Невельского вдоль берега материка, становится в среднем до начала декабря (т. е. примерно через месяц после начала ледообразования) и сохраняется без изменений границ в течение зимы до момента его разрушения в мае. Толщина припая в Погиби в конце марта - начале апреля в среднем составляет 160 см и варьирует от 119 до 190 см в зависимости от типа зимы.

Одновременно со становлением припая вдоль основного фарватера в ледяном покрове формируется (незамерзающий) приливной канал. Ширина канала в период максимального развития ледяного покрова составляет 2-3 мили (рис. 8).

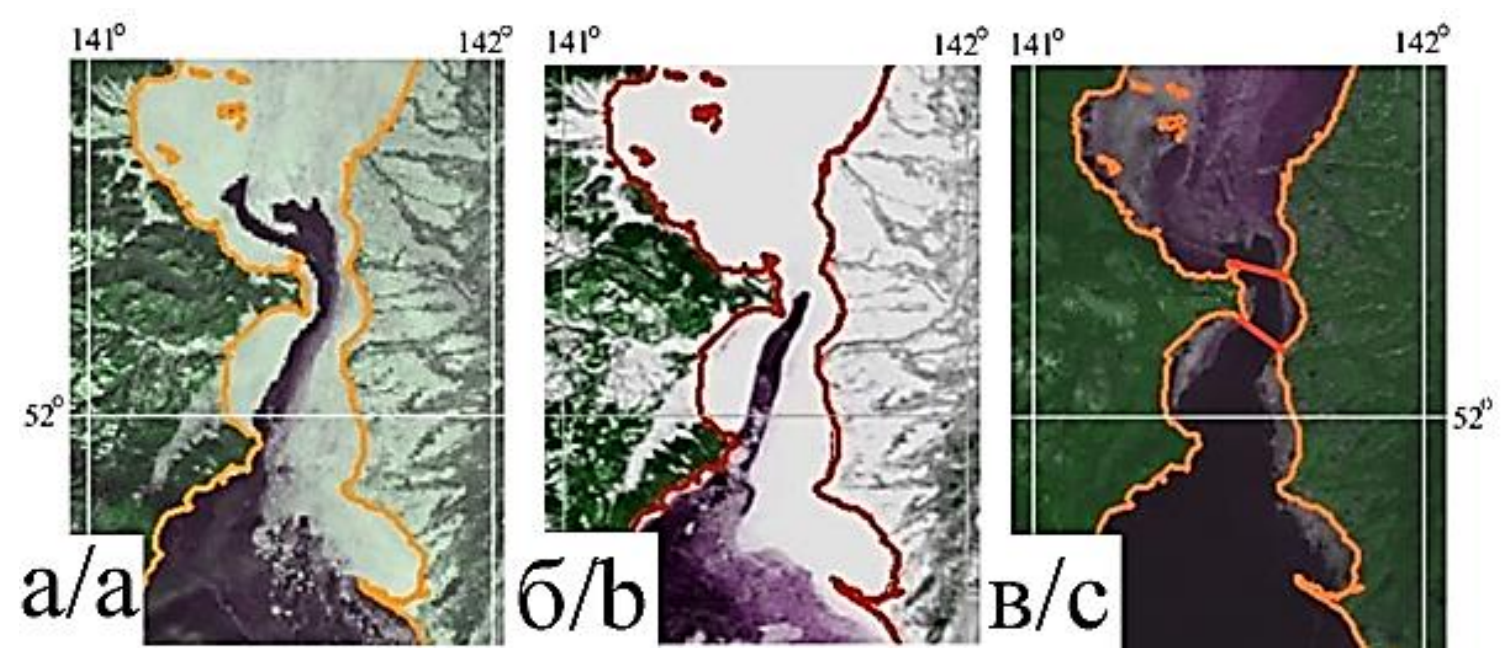

Рис. 8. Приливной канал на разных стадиях развития ледяного покрова в проливе Невельского: а) фаза становления; б) фаза максимального развития; в) фаза разрушения

Fig. 8. Tidal channel at different stages of ice cover development in the Nevelskogo Strait: a) phase of formation; б) phase of extremum; c) phase of destruction

Фазы развития ледяного покрова в Татарском проливе:

- становление - с начала ноября по конец января;

- максимального развития - с начала февраля до середины марта;

- разрушения - с середины марта до начала мая.

На фазе становления приливной канал, как правило, заполнен начальными видами льда толщиной до 10 см, на фазе максимального развития - серым льдом толщиной до 15 см. Из-за наличия сильных приливных течений сплошной ледяной покров в канале формируется крайне редко и на непродолжительное время. Следствием повышенной динамики ледяного покрова является многократное наслоение (в ограниченном пространстве) начальных видов и молодых льдов в результате чего могут формироваться ледяные образования размером до больших полей 
(>500 м) и толщиной до 30 см. На фазе разрушения ледообразование в канале происходит преимущественно в ночные часы. Толщина вновь образовавшегося льда составляет 2-3 см. Под воздействием солнечной радиации он полностью разрушается в дневное время.

Очищение происходит в начале второй декады мая, окончательное освобождение ото льда - 25 мая.

Остатки разрушающегося ледяного покрова Татарского пролива в исключительных случаях могут пересекать его северную границу при активной смене направления муссонной циркуляции весной.

Береговой уступ мыса Невельского устойчив к абразионным процессам: разрушение берега не превысит $1 \mathrm{~cm} /$ год, т. е. в течение 100 лет берег отступит не более чем на 1 м. Образование гротов и волноприбойных ниш в основании берегового уступа усиливается эффектом разрушения абразионного уступа под воздействием волн и льда. В целом скорость отступания береговой линии в районе мыса Невельского не превышает величины 5-10 м за 100 лет.

На основе дешифрирования аэрофотоснимков за 1952-1980 гг. В.В. Афанасьевым сделано заключение об отступании береговой линии на сахалинском берегу со скоростью менее 0,2 м/год. Берег острова находится в настоящее время в стадии геоморфологической или динамической зрелости: уклоны профиля аккумулятивных участков практически соответствуют их аналогам в составе древних абразионных поверхностей с отмершими клифами [36].

При небольших размерах волн зона взмучивания материала сокращается, оседая он выполаживает склон и создает условия для формирования прибрежного подводного вала. Выпадение осадка в нижних частях склона ослабляет волны у берега таким образом, что они могут взмучивать столько материала, сколько его оседает здесь же в момент смены направления волнового течения $[38,39]$. При уменьшении волнения взвесь выпадает на дно и одновременно перемещается к берегу, увеличивая крутизну склона $[40,41]$.

Материал гравийных пляжей относительно мало подвержен транспортирующему действию течений, поэтому формы мезорельефа, свойственные песчаным пляжам, в таких местах не встречаются или имеют малые размеры и иное строение. На гравийных пляжах формируются высокие береговые валы, а подводный склон является относительно приглубым.

\section{Заключение}

В результате проведенных исследований выявлено, что в районе исследования, заключенном между линиями створов м. Лазарева - м. Погиби на севере и м. Южный-м. Тык - на юге, климатические и гидрологические условия на всем протяжении имеют относительное сходство, что позволяет выделить его при районировании как самостоятельную единицу, обладающую следующими признаками:

- Метеорологические условия предопределяются астрономическими причинами и муссонной циркуляцией воздушных масс. Наименьшие значения суммарной солнечной радиации наблюдаются в районе в декабре от 69 до 123 МДж/м². В январе поток радиации увеличивается незначительно, он начинает заметно нарастать в марте и достигает максимума в июле. Экстремальные значения температуры воздуха - максимум $27,3{ }^{\circ} \mathrm{C}$ и минимум $-44,0{ }^{\circ} \mathrm{C}$ (амплитуда $71,3{ }^{\circ} \mathrm{C}$ ), что можно объяснить влиянием выноса воздушных масс с материка в зимний период. Продолжительность безморозного периода колеблется в Погиби от 88 до 186 дней (среднее значение 137). Суточные суммы осадков теплого периода достигали максимальных значений 88 мм в октябре, 81 - в августе и $78-$ в июле. Снежный покров держится от 153 до 216 дней. Ветер $\geq 30 \mathrm{~m} / \mathrm{c}$ случается весной и осенью ежегодно, иногда превышает $40 \mathrm{~m} / \mathrm{c}$. В районе пролива часто наблюдаются туманы, метели, сопровождаемые метелевым переносом снега. Грозы случается 4-5 раз в году. Пыльные бури бывают редко.

- Гидрологические условия в проливе сложные. Горизонтальная циркуляция воды в северной части пролива зимой имеет антициклоническую направленность, с мая по сентябрь действует циклоническая циркуляция. В целом весной на поверхности скорости движения вод составляют 2-7 cм/с, а летом уменьшаются до $1-4 \mathrm{~cm} / \mathrm{c}$. Изменения уровня моря в Татарском проливе находятся в диапазоне 3,2-4 м. Продолжительность ледового периода в умеренные типы зим составляет 201 сут. Толщина припая в Погиби в конце марта - начале апреля в среднем составляет 160 см и варьирует от 119 до 190 см в зависимости от типа зимы. Из-за сильных приливных течений сплошной ледяной покров в канале средней части пролива формируется крайне редко и на непродолжительное время. Следствием повышенной динамики ледяного покрова является многократное наслоение молодых льдов толщиной до 30 см.

- Берега в южной части пролива обладают устойчивостью к абразионным процессам и практически не разрушаются. Береговой уступ мыса Невельского устойчив к абразионным процессам. Разрушение берега не превышает 1 см/год. Скорость отступления береговой линии на сахалинском берегу у мыса Лах составляет менее 0,2 м/год. Берег находится в настоящее время в стадии геоморфологической зрелости.

Результаты изучения климатических и гидрологических условий показали, что строительство мостового перехода в проливе Невельского возможно. Наиболее благоприятными условиями для строительства сооружения обладает район, заключенный между линиями створов м. Лазарева-м. Погиби на севере и м. Южный-м. Тык - на юге, климатические и гидрологические условия на всем протяжении имеют относительное сходство, что позволило нам выделить его при районировании, выполненном с помощью моделирования, как самостоятельную единицу. Проведенные исследования позволяют отдать преимущество створу «Новый» (м. Невельского-м. Лах). 


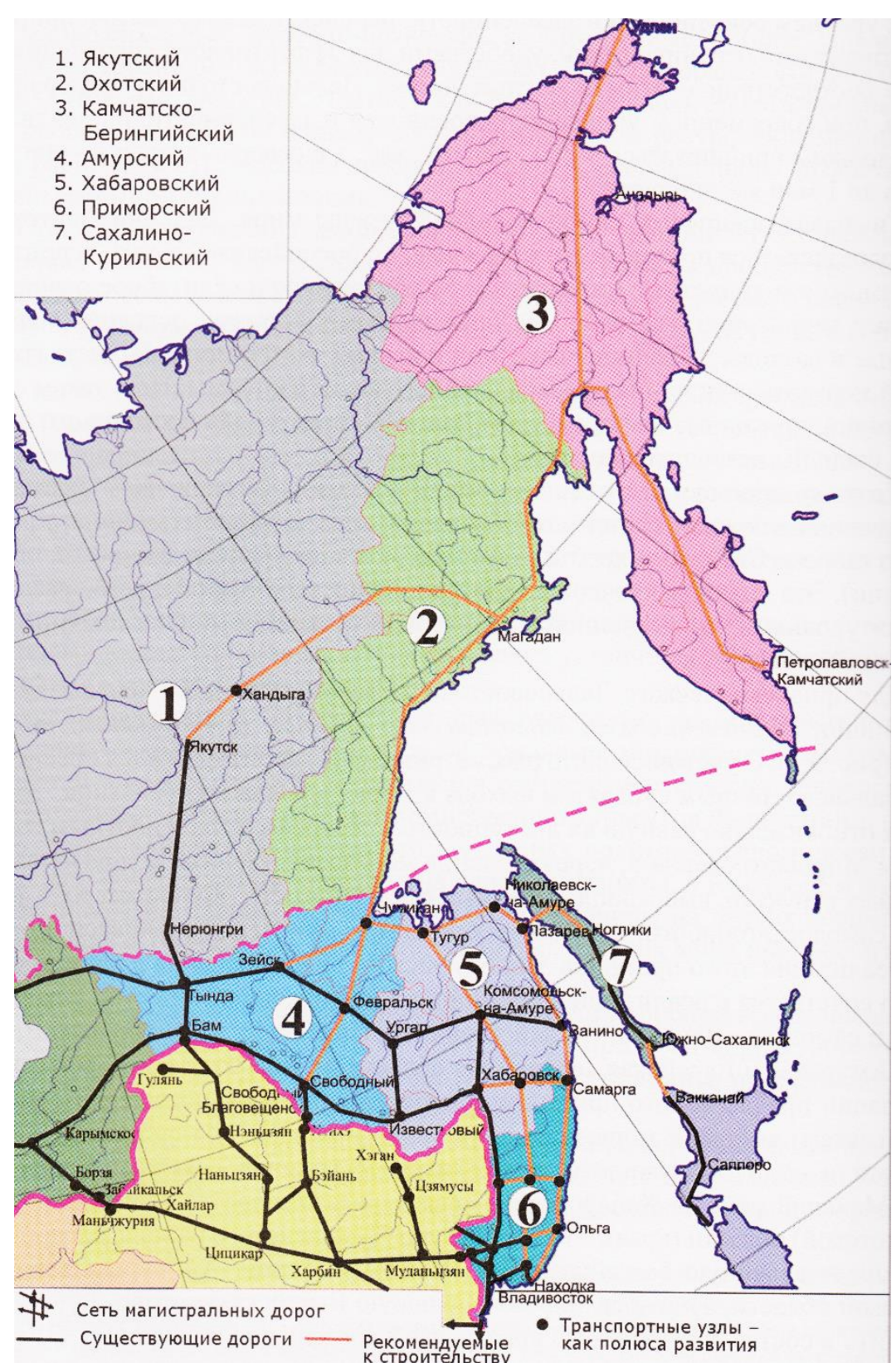

Pис. 9. Предполагаемый вариант экономического районирования и развития магистрального сообщения на Дальнем Востоке России с железнодорожным переходом с Сахалина на материк [43]

Fig. 9. Proposed variant of economic zoning and development of main line in Russian Far East with railway crossing from Sakhalin to mainland [43]

Различные варианты проектов соединения Сахалина с материком железнодорожным сообщением рассматривались в процессе технико-экономического обоснования, которое готовилось научными и проектными организациями на протяжении нескольких лет под эгидой ОАО «Гипростроймост» [42]. Окончательный выбор конструкции мостового перехода, безусловно, должны сделать специалисты, имеющие опыт создания сооружений подобного рода.

\section{СПИСОК ЛИТЕРАТУРЫ}

1. Мелкий В.А., Братков В.В., Верхотуров А.А. Геологические и геоморфологические предпосылки выбора места транспортного перехода «Материк-Сахалин» // Известия Томского политехнического университета. Инжиниринг георесурсов. -2020 . - Т. 331. - № 1. - C. 158-170.
Таким образом, еще раз подтверждается наличие всех условий для формирования сети магистральных дорог, задающих направления развития сетки экономических районов мезоуровня, которые рекомендуется создать на Дальнем Востоке на основании результатов крупномасштабных комплексных исследований геосистем региона (рис. 9) [43].

2. Бутков В.В. О возможности улучшения климата нашего побережья Японского моря. Докладная записка // Сайт «Мост на Сахалин. Япония-Сахалин-Европа» URL: http://mostsakhalin.ru/ publications/detail.php?ID=1588 (дата обращения 25.01.2020)

3. Костанов А.И. Самая восточная дорога России: очерки истории Сахалинской железной дороги. - М.: Транспорт, 1997. - 220 с. 
4. Недострой века: история о том, как Сталин пытался соединить Сахалин с материком // SakhalinMedia.ru. URL: https://sakhalinmedia.ru/news/531809 (дата обращения 25.01.2020)

5. Ведерников Г.П. Тайны объекта № 6: как я нашел чертежи тоннеля на Сахалин. URL: https://habinfo.ru/most-na-sahalin/ (дата обращения 25.01.2020)

6. Заключение Госстроя СССР № 115 сс по техническому проекту на строительство тоннельного перехода под Татарским проливом от 22.11.1952. ГА РФ. Ф. Р-5446. Оп. 60. Д. 7891. Л. 2-10. Подлинник // Исторический архив. - 2001. - № 6. C. 71-77. URL: https://alexanderyakovlev.org/fond/issuesdoc/60574 (дата обращения 25.01.2020).

7. Федеральная целевая программа «Модернизация транспортной системы России (2002-2010 годы)». Утверждена Постановлением Правительства РФ от 5 декабря 2001 г. № 848. Собрание законодательства Российской Федерации. - 2001. - №51. - ст. 4895. URL: http://www.szrf.ru/szrf/doc.phtml?nb=100\&issid=10020010510 $00 \&$ docid $=88$ (дата обращения 07.05.2020).

8. Лоции Татарского пролива, Амурского лимана и пролива Лаперуза, описывающие проход от порта Николаевск-наАмуре на север, в Охотское море. № 1402. Выпуск 1999 большая корректура по ГУНиО вып. 24 от 07.06.2003.

9. Кондратьев К.Я. Неопределенности данных наблюдений и численного моделирования климата // Метеорология и гидрология. - 2004. - № 4. - С. 93-119.

10. Климатические изменения в северной части АзиатскоТихоокеанского региона / В.И. Пономарев, Д.Д. Каплуненко, Е.В. Дмитриева, В.В. Крохин, П.В. Новороцкий // Дальневосточные моря России. - М.: Наука, 2007. - Кн. 1: Океанологические исследования. - С. 17-48.

11. Bradley R.S. Paleoclimatology: reconstructing climates of the quaternary. 3rd ed. - San Diego: Academic Press, 2014. - 675 p.

12. Trends and variations in south pacific island and ocean surface temperatures / C.K. Folland, M.J. Salinger, N. Jiang, N.A. Rayner // Journal of Climate. - 2003. - V. 16. - № 17. P. 2859-2874. URL: https://journals.ametsoc.org/doi/full/10.1175/ $1520-0442 \% 282003 \% 29016<2859 \% 3$ ATAVISP $>2.0 . C O \% 3 \mathrm{~B} 2$ (дата обращения 07.05.2020).

13. Observational needs of sea surface temperature / A.G. O'Carroll, E.M. Armstrong, H.M. Beggs, M. Bouali, K.S. Casey, G.K. Corlett, P. Dash, C.J. Donlon, C.L. Gentemann, J.L. Høyer A. Ignatov, K. Kabobah, M. Kachi, Y. Kurihara, I. Karagali,

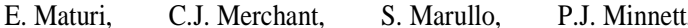
M. Pennybacker, B. Ramakrishnan, R. Ramsankaran, R Santoleri, S. Sunder, S. Saux Picart, J. Vázquez-Cuervo, W. Wimmer // Frontiers in Marine Science. - 2019. V. 6:420. - P. 1-27. URL: https://www.frontiersin.org/articles/ 10.3389/fmars.2019.00420/full (дата обращения 07.05.2020).

14. Longer and more frequent marine heatwaves over the past century / E.C.J. Oliver, M.G. Donat, M.T. Burrows, P.J. Moore, D.A. Smale, L.V. Alexander, J.A. Benthuysen, M. Feng, A.S. Gupta, A.J. Hobday, N.J. Holbrook, S.E. PerkinsKirkpatrick, H.A. Scannell, S.C. Straub, T. Wernberg // Nature Communications. - 2018. - V. 9:1324. URL: https://doi.org/ 10.1038/s41467-018-03732-9 (дата обращения 07.05.2020).

15. Theories on formation of an anomalous anticyclone in western North Pacific during El-Niño: A review / T. Li, B. Wang, B. Wu, T. Zhou, C.-P. Chang, R. Zhang // Journal of Meteorological Research. - 2017. - V.31. - Pp. 987-1006. https://link.springer.com/content/pdf/10.1007/s13351-017-71476.pdf (дата обращения 07.05.2020).

16. Cloud property datasets retrieved from AVHRR, MODIS, AATSR and MERIS in the framework of the Cloud_cci project / M. Stengel, S. Stapelberg, O. Sus, C. Schlundt, C. Poulsen, G. Thomas, M. Christensen, C. Carbajal Henken, R. Preusker, Jü. Fischer, A. Devasthale, U. Willén, K.-G. Karlsson, G.R. McGarragh, S. Proud, A.C. Povey, R.G. Grainger, J. Fokke Meirink, A. Feofilov, R. Bennartz, J.S. Bojanowski, R. Hollmann // Earth System Science Data. - 2017. - № 9. Iss. 2. - P. 881-904. URL: http://doi.org/10.5194/essd-9-8812017 (дата обращения 07.05.2020).

17. Hannachi A., Turner A.G. 20th century intraseasonal Asian monsoon dynamics viewed from Isomap // Nonlinear Processes
Geophysics. - 2013. - № 20. - Iss. 5. - P. 725-741. URL: https://doi.org/10.5194/npg-20-725-2013 (дата обращения 07.05.2020).

18. Krokhin V.V., Fil A.Y., Veryatin V.Y. Long-term variations in the frequency of typhoons and their connection with various formation factors // Russian Meteorology and Hydrology. 2017. - № 42. - P. 766-774. URL: https://doi.org/10.3103/ S1068373917120044 (дата обращения 07.05.2020).

19. Chongyin L., Shuqing S., Mingquan M. Origin of the TBOinteraction between anomalous East-Asian winter monsoon and ENSO cycle // Advances in Atmospheric Sciences. - 2001. V. 18. - № 4. - P. 554-566. URL: https://doi.org/10.1007/ s00376-001-0044-у (дата обращения 07.05.2020).

20. Wang J., Ikeda M. Arctic oscillation and Arctic sea-ice oscillation // Geophysical Research Letters. - 2000. - V. 27. Iss. 9. - P. 1287-1290. URL: https://doi.org/10.1029/ 1999GL002389 (дата обращения 07.05.2020).

21. On the decadal variability of the eddy kinetic energy in the Kuroshio Extension / Y. Yang, X.S. Liang, B. Qiu, S. Chen // Journal of Physical Oceanography. - 2017. - V. 47. - P. 1169-1187. URL: https://doi.org/10.1175/JPO-D-16-0201.1 (дата обращения 07.05.2020).

22. Ocean circulation signatures of North Pacific decadal variability / R.CJ. Wills, D.S. Battisti, C. Proistosescu, L.A. Thompson, D.L. Hartmann, K.C. Armour // Geophysical Research Letters. 2019. - V. 46. - № 3. - P. 1169-1187. URL: https://doi.org/ 10.1029/2018GL080716 (дата обращения 07.05.2020).

23. Northern hemisphere extratropical tropospheric planetary waves and their low-frequency variability: their vertical structure and interaction with transient eddies and surface thermal contrasts / H. Nakamura, T. Miyasaka, Y. Kosaka, K. Takaya, M. Honda // Climate dynamics: why does climate vary? Chap. 6. Geophys. Monogr / Eds. D.-Z. Sun, F. Bryan. - Washington, D. C., American Geophysical Union, 2010. - V. 189. - P. 149-179. URL: https://agupubs.onlinelibrary.wiley.com/doi/pdf/10.1029/ 2008GM000789 (дата обращения 07.05.2020).

24. Смирнов Н.П., Воробьев В.Н. Северо-Тихоокеанское колебание и динамика климата в северной части Тихого океана. - СПб.: РГГМУ, 2002. -122 c.

25. Minobe S. A 50-70 year climatic oscillation over the North Pacific and North America // Geophysical Research Letters. 1997. - V. 24. - Iss. 6. - P. 683-686. URL: https://doi.org/ 10.1029/97GL00504 (дата обращения 07.05.2020).

26. Научно-прикладной справочник по климату СССР: Серия 3. Многолетние данные. Ч. 1-6. Вып. 34. Сахалинская область. - Спб.: Гидрометеоиздат, 1990. - 352 с.

27. Научно-прикладной справочник по климату СССР. Серия 3. Многолетние данные. Ч. 1-6. Вып. 25. Хабаровский край, Амурская область. - Спб.: Гидрометеоиздат, 1992. - 582 с.

28. Пономарев В.И., Каплуненко Д.Д., Крохин В.В. Тенденции изменения климата во второй половине XX в. в СевероВосточной Азии, на Аляске и северо-западе Тихого океана // Метеорология и гидрология. - 2005. - № 2. - С. 15-26.

29. Погода в Погиби. Температура воздуха и осадки // Справочно-информационный портал «Погода и климат». URL: http://www.pogodaiklimat.ru/monitor.php?id=32027\&month=8 \&year=2018 (дата обращения 28.06.2020).

30. Гидрометеорология и гидрохимия морей: справочное издание. Проект «Моря». Т. VIII. Японское море. Вып. 1. Гидрометеорологические условия / под. ред. А.С. Васильева, Ф.С. Терзиева, А.Н. Косарева - Спб.: Гидрометеоиздат, 2003. $-395 \mathrm{c}$

31. Математическое моделирование условий функционирования экосистемы Татарского пролива / В.М. Пищальник, А.В. Леонов, В.С. Архипкин, В.А. Мелкий. - ЮжноСахалинск: СахГУ, 2011.- 104 с.

32. Yakunin L.P. Level and ice jams in the Amur Liman // The 14th International Symposium on Okhotsk Sea \& Sea Ice and International Workshop on Rational Evaluation of Ice Forces on Structures. - Hokkaido: Mombetsu, 1999. - P. 241-242.

33. Леонов А.В., Пищальник В.М., Чичерина О.В. Трансформация биогенных веществ в водах Татарского пролива (Японское море): анализ результатов математического моделирования // Водные ресурсы. - 2010. - Т. 37. - № 1. - С. 33-57. 
34. Пищальник В.М., Бобков А.О. Моделирование природных процессов на основе ГИС «Сахалинский шельф». - ЮжноСахалинск: СахГУ, 2008. - 103 с.

35. Природопользование, состояние и тенденции изменений морской среды прибрежных и сопредельных районов дальневосточных морей России. Единая система информации об обстановке в Мировом океане (ЕСИМО). URL: http://portal.esimo.ferhri.ru/portal/portal/poi (дата обращения 21.01.2020)

36. Афанасьев В.В., Игнатов Е.И., Чистов С.В. Морфология и динамика берегов и дна пролива Невельского - района проектирования постоянного железнодорожного перехода. Смоленск: Маджента, 2008. - 128 с.

37. Золотухин Д.Е., Ивельская Т.Н. Пространственная детализация магнитудно-географического критерия цунамиопасности землетрясений в Японском море // Проблемы анализа риска. - 2014. - Т. 11. - № 5. - С. 60-67.

38. Мониторинг переноса придонного потока осадков в прибрежно-морской зоне шельфа для выявления основных параметров моделей состояния экосистем / В.В. Ильин, В.А. Мелкий, А.А. Верхотуров, А.А. Гальцев, О.М. Зарипов, Д.В. Долгополов // Известия Томского политехнического университета. Инжиниринг георесурсов. - 2016. - Т. 327. № 1. - C. 105-115.

39. Hendricks M.R. Introduction to physical hydrology. - New York: Oxford University Press Inc., 2010. - 331 p.

40. Nelson K.S., Fringer O.B. Sediment dynamics in wind wavedominated shallow-water environments // Journal of Geophysical Research: Oceans. - 2018. - V. 123. - № 10. P. 6996-7015. URL: https://doi.org/10.1029/2018JC013894 (дата обращения 21.01.2020).

41. Sanford L.P. Modeling a dynamically varying mixed sediment bed with erosion, deposition, bioturbation, consolidation, and armoring // Computers \& Geosciences. - 2008. - № 34. Iss. 10. - P. 1263-1283. URL: https://doi.org/10.1016/j.cageo. 2008.02.011 (дата обращения 21.01.2020).

42. Васильков А.С. Проекты института «Гипростроймост» // Дороги. - 2013. - № 12. - С. 34-38.

43. Геосистемы Дальнего Востока России на рубеже XX-XXI вв.: в 3 т. Т. 3. Территориальные социально-экономические структуры / под ред. акад. П.Я. Бакланова, д.Г.н. М.Т. Романова. - Владивосток: Дальнаука, 2012. - 364 с.

Поступила 24.05.2020 г.

\section{Информация об авторах}

Мелкий В.A., доктор технических наук, ведущий научный сотрудник, Институт морской геологии и геофизики ДВО РАН

Верхотуров A.A., старший научный сотрудник, Институт морской геологии и геофизики ДВО РАН.

Пищальник В.M., доктор технических наук, заведующий лабораторией дистанционного зондирования Земли Сахалинского государственного университета.

Братков В.B., доктор географических наук, заведующий кафедрой географии Московского государственного университета геодезии и картографии. 


\title{
CLIMATIC AND HYDROLOGICAL FACTORS OPERATING IN THE AREA OF LEADING LINE FOR CONSTRUCTION OF BRIDGE «SAKHALIN-CONTINENT»
}

\author{
Vyacheslav A. Melkiy', \\ vamelkiy@mail.ru
}

\author{
Alexey A. Verkhoturov1, \\ ussr-91@mail.ru \\ Vladimir M. Pishchalnik²,
vpishchalnik@rambler.ru \\ Vitaliy V. Bratkov3, \\ vbratkov@mail.ru \\ 1 Institute of Marine Geology and Geophysics of the Far East Branch of Russian Academy of Science, \\ 1b, Nauki street, Yuzhno-Sakhalinsk, 693022, Russia. \\ 2 Sakhalin State University, \\ 290, Lenin street, Yuzhno-Sakhalinsk, 693008, Russia. \\ 3 Moscow State University of Geodesy and Cartography, \\ 4, Gorokhovsky bystreet, Moscow, 105064, Russia.
}

The expediency of transportation on the TRANS-Siberian railway is not in doubt for any of our contemporaries now, and its importance for development of Siberia and the Far East is quite obvious. However, this attitude to this transport artery was not formed immediately. Let us recall at least the fact that the Tomsk merchant class insisted that the road passed through Aleksandrovsk (now Novosibirsk). The decision of Tsar Alexander III on construction of the railway played crucial role. The built road contributed to the development of the cities through which it was laid. The situation with the decision on organization of the free movement from the mainland to Sakhalin seems to us similar to the one that was in front of laying of the line across Siberia. The issue will have to be addressed sooner or later. The laying of the highway to the island will give a powerful impetus to the social and economic development of the territories adjacent to the road and railway, which will pass through the bridge. In this article, we research specifics of climatic and hydrological factors that determine choice of type of hydraulic structures in the Nevelskogo Strait.

The relevance of the research is dictated by the need for comprehensive review of the conditions that determine the choice of the Tatar Strait crossing line by the bridge. After taking into account the influence of geological and geomorphological factors, we turn our attention to climatic, weather and hydrological processes that will have a permanent impact on construction and operation.

The aim of the research is to link together and analyze the data that characterize features of atmospheric and hydrosphere processes in narrow part of the Tatar Strait and conduct scientific research that will complement for engineering research and help identify based on simulation safest opening for construction of hydro-technical utilities that will connect opposite banks.

Materials and methods. The materials for the study were cartographic materials, data of remote sensing of the Earth, information on climatic and weather conditions, data of hydrological, meteorological, Oceanographic observations, information obtained as a result of research works and engineering surveys in which the authors participated, as well as information from literary sources. Mapping in the geographic information environment allowed creating thematic maps reflecting the dynamics of hydrometeorological processes. The obtained information was used in construction of models of water circulation, formation and degradation of ice cover in the Nevelskoy Strait with the use of geoinformation technologies. The authors took a direct part in research of the leading line "Novy» in 2001. As result of the research of the features of hydrometeorological conditions within the water area of the Nevelskogo Strait and its coasts, based on satellite monitoring data, observations at nearby weather stations, as well as confirmed by information obtained during engineering surveys, it was found that in area of the Nevelskoy Strait, adverse natural phenomena should be taken into account when choosing technical design solutions for selecting type of bridge or tunnel construction from mainland to Sakhalin. The spatial and temporal distribution of radiance in the area is due to astronomical reasons, decrease in duration of the sunshine in De-Kastri and Pogibi compared to Nikolaevsk-on-Amur is associated with frequent fogs that occur during atmospheric processes on border of land and sea. Extreme values of air temperature in Pogibi were registered at the Pogibi weather station - maximum of $27,3^{\circ} \mathrm{C}$ and a minimum of $-44,0{ }^{\circ} \mathrm{C}$. Index of continentality is very high (amplitude $-71,3^{\circ} \mathrm{C}$ ), which can be explained by the influence of air masses removal from mainland in winter period. The important indicator for projecting - duration of frost-free period-ranges in Pogibi from 88 to 186 days (average - 137). Daily precipitation totals during warm period reached maximum values of $88 \mathrm{~mm}$ in October, $81 \mathrm{~mm}$ in August, and $78 \mathrm{~mm}$ in July. Snow cover in Pogibi lasts from $153 \mathrm{to}$ 216 days. Winds of $\geq 30 \mathrm{~m} / \mathrm{s}$ occur annually in spring and autumn, sometimes exceeding $40 \mathrm{~m} / \mathrm{s}$. Fogs in described area are observed throughout year. Snowstorms in strait and on its coastal are very common. Any increase in wind in winter is accompanied by blizzard transfer of snow. Thunderstorms occur 4-5 times a year. Dust storms are rare. Horizontal water circulation in the Northern part of strait is anticyclical in winter, and cyclonic circulation is active from May to September. In general, in spring water movement speed on surface is $2-7 \mathrm{~cm} / \mathrm{s}$ and in summer it decreases to $1-4 \mathrm{~cm} / \mathrm{s}$. Changes in sea level in the Tatar Strait are in the range of 3,2-4,0 m. Duration of ice period at time moderate types of winters is 201 days. Collar ice in Pogibi in late March - early April averages $160 \mathrm{~cm}$ and varies from 119 to $190 \mathrm{~cm}$ depending on type of winter. Due to the strong tidal currents, the solid ice cover in channel of the middle part of strait is formed very rarely and on short time. The result of the increased ice cover dynamics is multiple layers of young ice up to $30 \mathrm{~cm}$ thick. Coastals in southern part of Strait are resistant to abrasion processes and practically do not collapse. The area enclosed between liding lines Lazarev cape - cape Pogibi in the North and cape South - cape Tyk - in the South has the most favorable conditions for the construction of bridge. 
Climatic and hydrological conditions throughout have relative similarity, which allowed us distinguish it when zoning as independent unit. The performed research allows us give an advantage to leading line «Novy» (cape Nevelskogo - cape Lakh).

\section{Key words:}

Hydrometeorological conditions, space images, thematic mapping, ice conditions, coastal abrasion, geodetic support, geoinformation technologies.

\section{REFERENCES}

1. Melkiy V.A., Bratkov V.V., Verhoturov A.A. Geological and geomorphological determinants for choosing the place of transport crossing «Continent-Sakhalin». Bulletin of the Tomsk Polytechnic University. Geo Assets Engineering, 2020, vol. 331, no. 1, pp. 158-170. In Rus.

2. Butkov V.V. O vozmozhnosti uluchsheniya klimata nashego poberezhya Yaponskogo morya. Dokladnaya zapiska [On the possibility of improving the climate of our coast of the Sea of Japan. Memo]. Most na Sakhalin. Yaponiya-Sakhalin-Evropa [Bridge to Sakhalin. Japan-Sakhalin-Europe»]. Available at: http:// mostsakhalin.ru/publications/detail.php?ID=1588 (accessed 25 January 2020).

3. Kostanov A.I. Samaya vostochnaya doroga Rossii: ocherki istorii Sakhalinskoy zheleznoy dorogi [The easternmost road in Russia: essays on the history of the Sakhalin railway]. Moscow, Transport Publ., 1997. $220 \mathrm{p}$.

4. Nedostroy veka: istoriva o tom, kak Stalin pytalsya soedinit Sakhalin s materikom [Incompleteness of century: the story of how Stalin tried to connect Sakhalin with the Mainland]. SakhalinMedia.ru. Available at: https://sakhalinmedia.ru/news/531809 (accessed 25 January 2020).

5. Vedernikov G.P. Tayny obekta No 6: kak ya nashel chertezhi tonnelya na Sakhalin [Secrets of object No 6: how I found the drawings of the tunnel on Sakhalin]. Available at: https://habinfo.ru/most-na-sahalin / (accessed 25 January 2020).

6. Zaklyuchenie Gosstroya SSSR № $115 \mathrm{ss}$ po tekhnicheskomu proektu na stroitelstvo tonnelnogo perekhoda pod Tatarskim prolivom ot 22.11.1952. GA RF. F. R-5446. Op. 60. D. 7891. L. 210. Podlinnik [The conclusion of Gosstroy of the USSR № $115 \mathrm{cc}$ Technical project for the construction of the tunnel crossing under the Tatar Strait from 22.11.1952. GARF. P-5446. Op. 60. D. 7891 L. 2-10. Original]. Istoricheskiy arkhiv, 2001, no. 6, pp. 71-77. Available at: https://alexanderyakovlev.org/fond/issues-doc/60574 (accessed 25 January 2020).

7. Federalnaya tselevaya programma «Modernizatsiya transportnoy sistemy Rossii (2002-2010 gody)». Utverzhdena Postanovleniem Pravitelstva RF ot 5 dekabrya $2001 \mathrm{~g}$. no 848. Sobranie zakonodatelstva Rossiyskoy Federatsii, 2001, № 51, st. 4895. [Federal target program «Modernization of the Russian transport system (2002-2010)». Approved by the government of the Russian Federation on December 5, 2001, № 848]. Available at: http://www.szrf.ru/szrf/doc.phtml?nb=100\&issid=1002001051000 \&docid $=88$ (accessed 7 May 2020).

8. Lotsii Tatarskogo proliva, Amurskogo limana i proliva Laperuza opisyvayushchie prokhod ot porta Nikolaevsk-na-Amure na sever, $v$ Okhotskoe more [Pilot's sailing direction of the Tatar Strait, Amur estuary and Laperouse Strait describing passage from the port of Nikolaevsk-on-Amur to North, in the sea of Okhotsk]. № 1402. Vypusk 1999 bolshaya korrektura po GUNiO vyp. 24 ot 07.06.2003.

9. Kondratev K.Ya. Neopredelennosti dannykh nablyudeniy i chislennogo modelirovaniya klimata [Uncertainties of observational data and numerical climate modeling]. Meteorologiya i gidrologiya, 2004, no. 4, pp. 93-119.

10. Ponomarev V.I., Kaplunenko D.D., Dmitrieva E.V., Krokhin V.V., Novorotskiy P.V. Klimaticheskie izmeneniya $v$ severnoy chasti Aziatsko-Tikhookeanskogo regiona. Dalnevostochnye morya Rossii. T. 1: Okeanologicheskie issledovaniya [Climate change in northern part of the Asia-Pacific region. Far Eastern seas of Russia. Vol. 1. Ocean studies]. Moscow, Nauka Publ., 2007. pp. 17-48.

11. Bradley R.S. Paleoclimatology: reconstructing climates of the quaternary. $3^{\text {rd }}$ ed. San Diego, Academic Press, 2014. 675 p.

12. Folland C.K., Salinger M.J., Jiang N., Rayner N.A. Trends and variations in south Pacific island and ocean surface temperatures. Journal of Climate, 2003, vol. 16, no. 17, pp. 2859-2874
Available at: https://journals.ametsoc.org/doi/full/10.1175/1520$0442 \% 282003 \% 29016<2859 \% 3$ ATAVISP $>2.0 . C O \% 3 \mathrm{~B} 2$ (accessed 7 May 2020).

13. O'Carroll A.G., Armstrong E.M., Beggs H.M., Bouali M., Casey K.S., Corlett G.K., Dash P., Donlon C.J., Gentemann C.L., Høyer J.L., Ignatov A., Kabobah K., Kachi M., Kurihara Y., Karagali I., Maturi E., Merchant C.J., Marullo S., Minnett P.J., Pennybacker M., Ramakrishnan B., Ramsankaran R., Santoleri R., Sunder S., Saux Picart S., Vázquez-Cuervo J., Wimmer W. Observational needs of sea surface temperature. Frontiers in Marine Science, 2019, vol. 6, Art. 420. Available at: https://www.frontiersin.org/articles/10.3389/fmars.2019.00420/full (accessed 7 May 2020).

14. Oliver E.C.J., Donat M.G., Burrows M.T., Moore P.J., Smale D.A., Alexander L.V., $\quad$ Benthuysen J.A., $\quad$ Feng M., Gupta A.S., Hobday A.J., Holbrook N.J., Perkins-Kirkpatrick S.E., Scannell H.A., Straub S.C., Wernberg T. Longer and more frequent marine heatwaves over the past century. Nature Communications, 2018, no. 9, Art. 1324. Available at: https://doi.org/10.1038/s41467-018-03732-9 (accessed 7 May 2020).

15. Li T., Wang B., Wu B., Zhou T., Chang C.-P., Zhang R. Theories on formation of an anomalous anticyclone in western North Pacific during El Niño: A review. Journal of Meteorological Research, 2017, vol.31, Pp. 987-1006. https://link.springer.com/ content/pdf/10.1007/s13351-017-7147-6.pdf (accessed 7 May 2020).

16. Stengel M., Stapelberg S., Sus O., Schlundt C., Poulsen C., Thomas G., Christensen M., Carbajal Henken C., Preusker R., Fischer J., Devasthale A., Willén U., Karlsson K.-G., McGarragh G.R., $\quad$ Proud S., $\quad$ Povey A.C., $\quad$ Grainger R.G., Meirink J.F., $\quad$ Feofilov A., $\quad$ Bennartz R., Bojanowski J.S., Hollmann R. Cloud property datasets retrieved from AVHRR, MODIS, AATSR and MERIS in the framework of the Cloud_cci project. Earth System Science Data, 2017, no. 9, Iss. 2, pp. 881904. Available at: https://doi.org/10.5194/essd-9-881-2017 (accessed 7 May 2020).

17. Hannachi A., Turner A.G. $20^{\text {th }}$ century intraseasonal Asian monsoon dynamics viewed from Isomap. Nonlinear Processes in Geophysics, 2013, no. 20, Iss. 5, pp. 725-741. Available at: https://doi.org/10.5194/npg-20-725-2013 (accessed 7 May 2020).

18. Krokhin V.V., Fil A.Y., Veryatin V.Y. Long-term variations in the frequency of typhoons and their connection with various formation factors. Russian Meteorology and Hydrology, 2017, no. 42, pp. 766-774 Available at: https://doi.org/10.3103/ S1068373917120044 (accessed 7 May 2020).

19. Chongyin L., Shuqing S., Mingquan M. Origin of the TBOinteraction between anomalous East-Asian winter monsoon and ENSO cycle. Advances in Atmospheric Sciences, 2001, vol. 18, no. 4, pp. 554-566. Available at: https://doi.org/10.1007/s00376001-0044-y

20. Wang J., Ikeda M. Arctic oscillation and Arctic sea-ice oscillation. Geophysical Research Letters, 2000, vol. 27, Iss. 9, pp. 1287-1290. Available at: https://doi.org/10.1029/1999GL002389 (accessed 7 May 2020).

21. Yang Y., Liang X.S., Qiu B., Chen S. On the decadal variability of the eddy kinetic energy in the Kuroshio Extension. Journal of Physical Oceanography, 2017, vol. 47, pp. 1169-1187. Available at: https://doi.org/10.1175/JPO-D-16-0201.1 (accessed 7 May 2020).

22. Wills R.CJ., Battisti D.S., Proistosescu C., Thompson L.A., Hartmann D.L., Armour K.C. Ocean circulation signatures of North Pacific decadal variability. Geophysical Research Letters, 2019, vol. 46, no. 3, pp. 1690-1701. Available at: https://doi.org/ 10.1029/2018GL080716 (accessed 7 May 2020).

23. Nakamura H., Miyasaka T., Kosaka Y., Takaya K., Honda M. Northern Hemisphere extratropical tropospheric planetary waves and their low-frequency variability: their vertical structure and interaction with transient eddies and surface thermal contrasts. 
Climate dynamics: why does climate vary? Chap. 6. Geophys. Monogr. Eds. D. Sun, F. Bryan. Washington, D. C., American Geophysical Union, 2010. Vol. 189, pp. 149-179. Available at: https://agupubs.onlinelibrary.wiley.com/doi/pdf/10.1029/2008GM 000789 (accessed 7 May 2020).

24. Smirnov N.P., Vorobev V.N. Severo-Tikhookeanskoe kolebanie i dinamika klimata $v$ severnoy chasti Tikhogo okeana [NorthPacifical fluctuation and climate dynamics in the North Pacific]. St-Petersburg, RGGMU Publ., 2002. 122 p.

25. Minobe S. A 50-70 year climatic oscillation over the North Pacific and North America. Geophysical Research Letters, 1997, vol. 24, Iss. 6, pp. 683-686. Available at: https://doi.org/10.1029/ 97GL00504 (accessed 7 May 2020).

26. Nauchno-prikladnoy spravochnik po klimatu SSSR: Ser. 3. Mnogoletnie dannye. Ch. 1-6, Vyp. 34, Sakhalinskaya oblast [Scientific and applied guide to the climate of the USSR: Series 3. Multiyear data. P. 1-6, Iss. 34, Sakhalin region]. St-Petersburg, Gidrometeoizdat Publ., 1990. 352 p.

27. Nauchno-prikladnoy spravochnik po klimatu SSSR: Ser.3. Mnogoletnie dannye. Ch. 1-6, Vyp. 25, Khabarovskiy kray, Amurskaya oblast [Scientific and applied guide to the climate of the USSR: Series 3. Multiyear data. P. 1-6, Iss. 25. Khabarovsky kray, Amur region]. St-Petersburg, Gidrometeoizdat Publ., 1992. $582 \mathrm{p}$.

28. Ponomarev V.I., Kaplunenko D.D., Krokhin V.V. Tendentsii izmeneniya klimata vo vtoroy polovine XX v. v SeveroVostochnoy Azii, na Alyaske i severo-zapade Tikhogo okeana [Climate change trends in the second half of XX century in northeast Asia, Alaska, and the Pacific Northwest]. Meteorologiya i gidrologiya, 2005, no. 2, pp. 15-26.

29. Pogoda v Pogibi. Temperatura vozdukha i osadki [Weather in Pogibi. Air temperature and precipitation]. Weather and climate. Available at: http://www.pogodaiklimat.ru/monitor.php?id= $32027 \&$ month $=8$ \&year $=2018$ (accessed 28 June 2020).

30. Vasileva A.S., Terzieva F.S., Kosareva A.N. Gidrometeorologiva i gidrokhimiya morey: spravochnoe izdanie. Proekt «Morya». T.VIII. Yaponskoe more. Gidrometeorologicheskie usloviya [Hydrometeorology and hydrochemistry of seas: reference publication. The Seas Project. Vol. VIII. Sea of Japan. Ed. 1. Hydrometeorological conditions]. St-Petersburg, Gidrometeoizdat Publ., 2003. 395 p.

31. Pishchalnik V.M., Leonov A.V., Arkhipkin V.S., Melkiy V.A. Matematicheskoe modelirovanie usloviy funktsionirovaniya ekosistemy Tatarskogo proliva [Mathematical modeling of functioning conditions of the Tatar Strait ecosystem]. YuzhnoSakhalinsk, SakhGU, 2011. $104 \mathrm{p}$

32. Yakunin L.P. Level and ice jams in the Amur Liman. The $14^{\text {th }}$ International Symposium on Okhotsk Sea \& Sea Ice and International Workshop on Rational Evaluation of Ice Forces on Structures. Hokkaido, Mombetsu, 1999. pp. 241-242.

33. Leonov A.V., Pishchalnik V.M., Chicherina O.V. Transformations of biogenic substances in Tatar Strait water (the Sea of Japan): analysis of mathematical modeling results. Water Resources, 2010, vol. 37, no. 1, pp. 33-57. https://doi.org/10.1134/S0097807810010033

34. Pishchalnik V.M., Bobkov A.O. Modelirovanie prirodnykh protsessov na osnove GIS «Sakhalinskiy shelf» [Modeling of natural processes based on the GIS «Sakhalin shelf»]. YuzhnoSakhalinsk, SakhGU Publ., 2008. 103 p.

35. Prirodopolzovanie, sostoyanie $i$ tendentsii izmeneniy morskoy sredy pribrezhnykh $i$ sopredelnykh rayonov dalnevostochnykh morey Rossii. Edinaya sistema informatsii ob obstanovke $v$ Mirovom okeane (ESIMO) [Nature management, State and Trends of changes in the Marine environment of the Coastal and Adjacent areas of the Russian Far Eastern seas]. Available at: http://portal.esimo. ferhri.ru/portal/portal/poi (accessed 21 January 2020)

36. Afanasev V.V., Ignatov E.I., Chistov S.V. Morfologiya i dinamika beregov $i$ dna proliva Nevelskogo rayona proektirovaniya postoyannogo zheleznodorozhnogo perekhoda [Morphology and dynamics of shores and bottom of the Nevelskogo Strait - district of design of the permanent railway crossing]. Smolensk, Madzhenta Publ., 2008. 128 p.

37. Zolotukhin D.E., Ivelskaya T.N. Prostranstvennaya detalizatsiya magnitudno-geograficheskogo kriteriya tsunamiopasnosti zemletryaseniy v Yaponskom more [Spatial detail of magnitudegeographical criterion for tsunami hazard of earthquakes in the Sea of Japan]. Problemy analiza riska, 2014, vol. 11, no. 5, pp. 60-67.

38. Ilin V.V., Melkiy V.A., Verkhoturov A.A., Galtsev A.A., Zaripov O.M., Dolgopolov D.V. Monitoring of the near-bottom flow of the sediments in the coastal zone of the shelf to identify the main parameters of the models of the ecosystems. Bulletin of the Tomsk Polytechnic University. Geo Assets Engineering, 2016, vol. 327, no. 1, pp. 105-115. In Rus.

39. Hendricks M.R. Introduction to physical hydrology. New York, Oxford University Press Inc., 2010. $331 \mathrm{p}$.

40. Nelson K.S., Fringer O.B. Sediment dynamics in wind wavedominated shallow-water environments. Journal of Geophysical Research: Oceans, 2018, vol. 123, no. 10, pp. 6996-7015. Available at: https://doi.org/10.1029/2018JC013894 (accessed 21 January 2020).

41. Sanford L.P. Modeling a dynamically varying mixed sediment bed with erosion, deposition, bioturbation, consolidation, and armoring. Computers \& Geosciences, 2008, no. 34, Iss. 10, pp. 1263-1283. Available at: https://doi.org/10.1016/j.cageo.2008.02.011 (accessed 21 January 2020).

42. Vasilkov A.S. Proekty instituta «Giprostroymost» [The projects of the Institute «Giprostroymost»]. Dorogi, 2013, no. 12, pp. 34-38.

43. Geosistemy Dalnego Vostoka Rossii na rubezhe XX-XXI vv. T. 3. Teritorialnye sotsialno-ekonomicheskie truktury [Geosystems of Far East of Russia on boundary of XX-XXI centuries. Vol. 3. Territorial social-economic structures]. Eds. P.Ya. Baklanov, M.T. Romanov. Vladivostok, Dalnauka Publ., 2012. 364 p.

Received: 24 May 2020.

\section{Information about the authors}

Vyacheslav A. Melkiy, Dr. Sc., leading researcher, Institute of Marine Geology and Geophysics of the Far East Branch of Russian Academy of Science.

Alexey A. Verkhoturov, Cand. Sc., senior researcher, Institute of Marine Geology and Geophysics of the Far East Branch of Russian Academy of Science.

Vladimir M. Pishchalnik, Dr. Sc., head of the laboratory for remote sensing of the earth of the Sakhalin State University.

Vitaliy V. Bratkov, Dr. Sc., head of Geography department, Moscow State University of Geodesy and Cartography. 